\title{
Anti-apoptotic proteins and catalase-dependent apoptosis resistance in nickel chloride-transformed human lung epithelial cells
}

\author{
YU-XIU YANG ${ }^{1}$, XIU-LING LI ${ }^{1}$, LEI WANG ${ }^{2}$, SHUANG-YIN HAN ${ }^{1}$, YAN-RUI ZHANG ${ }^{1}$, \\ POYIL PRATHEESHKUMAR ${ }^{2}$, XIN WANG $^{2}$, JIAN LU $^{2}$, YUAN-QIN YIN $^{2}$, LI-JUAN SUN ${ }^{2}$, \\ AMIT BUDHRAJA ${ }^{2}$, ANDREW J. HITRON ${ }^{2}$ and SONG-ZE DING ${ }^{1,2}$ \\ ${ }^{1}$ Department of Internal Medicine, Henan Provincial People's Hospital, Zhengzhou University, Zhengzhou, \\ Henan 450000, P.R. China; ${ }^{2}$ Graduate Center for Toxicology, College of Medicine, \\ University of Kentucky, Lexington, KY 40536, USA
}

Received April 15, 2013; Accepted May 29, 2013

DOI: 10.3892/ijo.2013.2004

\begin{abstract}
Chronic exposure to nickel compounds is associated with increased incidence of certain types of human cancer, including lung and nasal cancers. Despite intensive investigation, the oncogenic processes remain poorly understood. Apoptosis resistance is a key feature for tumor cells to escape physiological surveillance and acquire growth advantage over normal cells. Although $\mathrm{NiCl}_{2}$ exposure induces transformation of human lung epithelial cells, little information is available with regard to its molecular mechanisms, it is also not clear if the transformed cells are apoptosis resistant and tumorigenic. We explored the apoptosis resistance properties of nickel chloride-transformed human lung epithelial cells and the underlying mechanisms. The results showed that transformed BEAS-2B human lung epithelial cells are resistant to $\mathrm{NiCl}_{2}$-induced apoptosis. They have increased Bcl-2, Bcl-xL and catalase protein levels over the passage matched non-transformed counterparts. The mechanisms of apoptosis resistance are mitochondria-mediated and caspase-dependent. Forced overexpression of Bcl-2, $\mathrm{Bcl}-\mathrm{xL}$ and catalase proteins reduced $\mathrm{NiCl}_{2}$-induced cell death; siRNA-mediated knockdown of their expression sensitized the cells to nickel-induced apoptosis, suggesting that Bcl-2, Bcl-xl and catalase protein expression plays a critical role in apoptosis resistance. Akt also participates in this process, as its overexpression increases Bcl-xL protein expression levels and attenuates $\mathrm{NiCl}_{2}$-induced apoptosis. Furthermore, transformed cells are tumorigenic in a xenograft model. Together, these results demonstrate that nickel-transformed cells are apoptosis-resistant and
\end{abstract}

Correspondence to: Dr Song-Ze Ding, Department of Internal Medicine, Henan Provincial People's Hospital, Zhengzhou University, no. 7 Wei Wu Road, Zhengzhou, Henan 450000, P.R. China E-mail: dingsongze@hotmail.com

Key words: Bcl-2, Bcl-xL, apoptosis, nickel, BEAS-2B cell, oxidative stress, carcinogenesis, tumor, lung cancer tumorigenic. Increased expression of $\mathrm{Bcl}-2$, Bcl-xL and catalase proteins are important mechanisms contributing to transformed cell oncogenic properties.

\section{Introduction}

Nickel is a ubiquitous environmental metal, widely used in industrial processes. Nickel compounds are important human carcinogens. Epidemiologically, chronic and professional exposure to nickel compounds is associated with increased incidence of certain human cancer, including lung and nasal cancers $(1,2)$. Both the soluble and insoluble forms of nickel compounds are detrimental to health with the insoluble form possesses higher risk, such as nickel oxide and nickel subsulfide $(3,4)$. In 1990, nickel is classified as established carcinogen to humans (group 1) by International Agency for Research on Cancer (IARC) $(3,4)$.

Several mechanisms have been proposed for nickel-induced carcinogenesis. These include production of reactive oxygen species (ROS), induction of DNA damage $(1,4)$, alteration of epigenetic changes such as histone modifications $(5,6)$, disruption of cellular iron homeostasis (7), and activation of oncogenic pathways $(8,9)$. Despite intensive investigation, the molecular features of nickel-induced oncogenic transformation, which are essential components in tumor initiation and progression, remain elusive.

Apoptosis (programmed cell death) is a key mechanism to maintain normal cell homeostasis, it removes cells that carry abnormal genetic information and keeps the functional integrity of organ or cell populations (10). Aberrant expression of anti-apoptotic protein is a common feature to many types of malignancy including lung, breast, prostate cancer, melanoma and leukemia. Their overexpression confers the cancer cells a growth advantage to escape from physiological surveillance and promote tumor formation $(10,11)$. Recent studies also suggest that activation of oncogenic pathways mediate nickel chloride $\left(\mathrm{NiCl}_{2}\right)$-induced epithelial cell oncogenic transformation accompanied by enhanced $\mathrm{Bcl}-2$, Bcl-xL protein expression (9). 
$\mathrm{Bcl}-2$, and $\mathrm{Bcl}-\mathrm{xL}$ protein expression has been implicated in cancer and cell transformation $(10,12)$, therefore, we hypothesized that their overexpression in transformed cells may lead to apoptosis resistance contributing to nickel-induced carcinogenesis. However, it is not clear if a metal compounds such as nickel might induce apoptosis resistance in transformed cells and the underlying molecular mechanisms, neither is it known if these cells are tumorigenic. Therefore, we investigated the role of Bcl-2, Bcl-xL and ROS scavenging enzyme in nickel-induced apoptosis resistance and the molecular mechanisms, which are necessary steps to understand nickel-induced carcinogenesis.

We demonstrate in this study that increased $\mathrm{Bcl}-2, \mathrm{Bcl}-\mathrm{xL}$ and ROS scavenging enzyme expression are important in conferring $\mathrm{NiCl}_{2}$-transformed BEAS-2B cell apoptosis resistance. The mechanisms are mitochondria-mediated and caspase-dependent. Transformed cells are also tumorigenic with accompanied oncogenic protein expression. The results characterize the oncogenic properties of nickel-transformed human lung epithelial cells and provide insight into nickelinduced carcinogenesis.

\section{Materials and methods}

Cell culture and reagents. Immortalized normal human bronchial epithelial cell line, BEAS-2B was purchased from American Type Culture Collection (ATCC, Manassas, VA). $\mathrm{NiCl}_{2}$-transformed BEAS-2B cells were isolated from soft agar by low dose $\mathrm{NiCl}_{2}$ exposure with BEAS-2B cells for 6 months (9). These cells showed anchorage-independent growth, proliferated faster, but were morphologically similar to normal BEAS-2B cells (9). BEAS-2B cells that stably express catalase (OriGene, Rockville, MD), Akt and dominant negative-Akt (DN-Akt) which is a kinase-dead (K179M) mutant, were generated by integration of catalase, wild-type Akt (Akt-C), DN-Akt expression vectors into BEAS-2B cells and selected with G418. Characterization of these cells has been described before $(13,14)$. Tissue culture reagents were purchased from Gibco (Invitrogen, Carlsbad, CA). Cells were maintained in DMEM medium supplemented with $10 \%$ fetal bovine serum and antibiotics at $37^{\circ} \mathrm{C}$ in a humidified $10 \% \mathrm{CO}_{2}$ incubator.

Nickel chloride $\left(\mathrm{NiCl}_{2}\right)$ was purchased from Sigma Chemical Company (St. Louis, MO, USA). Polyclonal and monoclonal antibodies against phospho-Akt at Ser473 (\#9275), phospho-Stat3 (\#9145), Bcl-xL (\#2764), catalase (\#8841), HIF-1 $\alpha$ (\#3434), cleaved caspase-3 (\#9661), cleaved caspase-7 (\#9491), cleaved PARP (\#9542), peroxiredoxin 1 (\#8499) were purchased from Cell Signaling Technology (Danvers, MA). Bcl-2 was from Dako (Carpinteria, CA). SOD1 (sc-11407), SOD2 (sc-130345), $\beta$-actin (sc-47778), lamin A/C (sc-6215), Akt1 (sc-5298) and NF-кB p50 (sc-7178) were purchased from Santa Cruz Biotechnology (Santa Cruz, CA).

Assays for apoptosis. Apoptosis was determined by Annexin V/ propidium iodide (PI) staining kit (BD Pharmingen, San Jose, CA). In some experiments, due to the expression of green fluorescence protein (GFP) interfering with Annexin V-FITC reading, a double stain apoptosis detection kit using Hoechst 33342/PI staining (GenScript, Piscataway, NJ) was chosen to replace Annexin V-FITC. Briefly, cells $\left(1 \times 10^{6}\right)$ treated with or without $\mathrm{NiCl}_{2}$ were collected and washed once with cold PBS, they were stained with $5 \mu \mathrm{l}$ of Annexin V-FITC or Hoechst 33342 followed by $10 \mu \mathrm{l}$ of PI $(5 \mu \mathrm{g} / \mathrm{ml})$ in binding buffer [10 mmol/l HEPES (pH 7.4), $140 \mathrm{mmol} / \mathrm{l} \mathrm{NaOH}$, and $2.5 \mathrm{mmol} / 1 \mathrm{CaCl}_{2}$ ] for $15 \mathrm{~min}$ at room temperature in dark. The apoptotic cells were determined using a Becton-Dickinson FACScan cytofluorometer. Both early apoptotic (Annexin V or Hoechst 33342-positive and PI-negative) and late apoptotic (Annexin V or Hoechst 33342-positive and PI-positive) cells were included in cell death determinations.

Western blot analyses. Cell lysates were collected in lysis buffer (50 mM Tris-HCl, pH 7.4, 1 mM EDTA, $150 \mathrm{mM} \mathrm{NaCl}$, $1 \% \mathrm{NP}-40,0.25 \% \mathrm{Na}$-deoxycholate, and $1 \mu \mathrm{g} / \mathrm{ml}$ of aprotinin, leupeptin and pepstatin). Proteins $(20 \mu \mathrm{g})$ were separated on $10 \%$ SDS polyacrylamide gels. Proteins were subsequently transferred from gel onto nitrocellulose membrane (Bio-Rad, Hercules, CA). Membranes were blocked for $1 \mathrm{~h}$ at room temperature in Tris-buffered saline plus $0.01 \%$ Tween-20 (TBS-T) in 5\% non-fat dry milk (pH 7.4). Various antibodies were diluted at 1:1,000 in TBS-T with 5\% non-fat dry milk solution, incubated with membrane at $4^{\circ} \mathrm{C}$ overnight and washed three times with TBS-T. The secondary antibody, horseradish peroxidase (HRP)-conjugated antibodies, diluted at 1:2,500 in TBS-T with 5\% non-fat dry milk were incubated with membrane at room temperature for 2-3 h. Signal was detected with an enhanced chemiluminescence detection kit (Perkin Elmer Life Sciences, Boston, MA). In each experiment, either anti- $\beta$-actin or anti-lamin $\mathrm{A} / \mathrm{C}$ antibody was reprobed to monitor protein loading. Image quantification was processed by ImageJ software (NIH, Rockville, MD). In some experiments, mean densitometry values were adjusted with $\beta$-actin and expressed as fold changes over the appropriate controls.

Quantitative RT-PCR for gene expression. Total RNA from BEAS-2B cells was extracted using TRIzol reagents as described previously (15). Reverse transcription of $2 \mu \mathrm{g}$ of total cellular RNA was performed in a final volume of $20 \mu \mathrm{l}$ containing $5 \mathrm{X}$ first strand buffer (Invitrogen), $1 \mathrm{mM}$ of each dNTP, 20 units of placental RNase inhibitor, $5 \mu \mathrm{M}$ random hexamer and 9 units of Moloney murine leukemia virus reverse transcriptase (Invitrogen). After incubation at $37^{\circ} \mathrm{C}$ for $45 \mathrm{~min}$, the samples were heated for $5 \mathrm{~min}$ at $92^{\circ} \mathrm{C}$ to end the reaction, diluted at $1: 4$ and stored at $-20^{\circ} \mathrm{C}$ until PCR. cDNA ( $2 \mu \mathrm{l}$ ) was subjected to real-time quantitative PCR using the real-time PCR detection systems (Bio-Rad, Hercules, CA) with SYBR-Green I (Molecular Probes, Eugene, OR) as a fluorescent reporter. Threshold cycle number of duplicate reactions was determined using PCR software and levels of selected gene mRNA expression were normalized to hypoxanthine phosphoribosyltransferase (HPRT) levels using the formula $2^{(R t-E t)}$; where $R t$ is the mean threshold cycle for the reference gene HPRT and $E t$ is the mean threshold cycle for experimental gene. Data are expressed as arbitrary units and adjusted to fold changes over the non-stimulated control cells. Primer sequences are provided in Table I.

Measurement of mitochondrial membrane potential. Mitochondrial membrane potential $(\Delta \Psi \mathrm{m})$ was monitored using MitoProbe JC-1 assay kit (Invitrogen). 5,5',6,6'-tetrachloro1,1',3,3'-tetraethylbenzimidazolyl-carbocyanine iodide (JC-1), 
Table I. PCR primers.

\begin{tabular}{ll}
\hline Gene name & \multicolumn{1}{c}{ For RT-PCR $\left(5^{\prime} \rightarrow 3^{\prime}\right)$} \\
\hline$B c l-2$ & Fwd: GCCTTCTTTGAGTTCGGTGG \\
& Rev: ATCTCCCGGTTGACGCTCT \\
$B c l-x L$ & Fwd: GAGCTGGTGGTTGACTTTCTC \\
& Rev: TCCATCTCCGATTCAGTCCCT \\
$H p r t$ & Fwd: TTGGAAAGGGTGTTTATTCCTCA \\
& Rew: TCCAGCAGGTCAGCAAAGAA \\
\hline
\end{tabular}

Hprt, hypoxanthine phosphoribosyltransferase.

a lipophilic cationic fluorescence dye, is capable of selectively entering mitochondria, where it forms monomers, and emits green fluorescence (FL-1) when $\Delta \Psi \mathrm{m}$ is relatively low. At high $\Delta \Psi \mathrm{m}, \mathrm{JC}-1$ aggregates and gives red fluorescence (FL-2) (16). Thus the red and green fluorescence of JC-1 reflect the change of $\Delta \Psi \mathrm{m}$ of the mitochondrial membrane. Briefly, BEAS-2B or transformed BEAS-2B cells $\left(5 \times 10^{5}\right)$ were seeded into $60-\mathrm{mm}$ culture dishes and treated with $\mathrm{NiCl}_{2}$ for $16 \mathrm{~h}$. Cells were trypsinized, washed in ice-cold PBS and incubated with $2 \mu \mathrm{M}$ JC- 1 at $37^{\circ} \mathrm{C}$ for $20 \mathrm{~min}$. Cells were washed once with PBS and analyzed by FACScan cytofluorometer.

Caspase activity assay. Caspase activity was assessed using the luminescent Caspase-Glo ${ }^{\circledR}$ 3/7 assay system (Promega, Madison, WI) following manufacturer's instructions. Briefly, BEAS-2B or transformed BEAS-2B cells were treated with or without $\mathrm{NiCl}_{2}$ at $1.5 \mathrm{mM}$ for $16 \mathrm{~h}$. Caspase-Glo 3/7 reagent (100 $\mu \mathrm{l}$ ) was added into 96-well plates and incubated for $1 \mathrm{~h}$ at room temperature. The luminescence was measured using a Glomax ${ }^{\mathrm{TM}} 96$ microplate luminometer (Promega). Z-VAD-FMK (carbobenzoxy-valyl-alanyl-aspartyl-[O-methyl]fluoromethylketone), a cell-permeant pan-caspase inhibitor that irreversibly binds to the catalytic site of caspase proteases that inhibit induction of apoptosis was added $30 \mathrm{~min}$ before nickel stimulation at $20 \mu \mathrm{M}$ solution in DMSO (Promega). Data were collected and expressed as fold change over the control without $\mathrm{NiCl}_{2}$ treatment.

Small interfering RNA transfection. Transfection procedures followed manufacturer's recommended protocol. Small interference RNA (siRNA) for Bcl-2 (sc-29214), Bcl-xL (sc-43630) were purchased from Santa Cruz Biotechnology (Santa Cruz, CA). Scrambled control and siRNA for catalase (s-2443) were obtained from Ambion (Austin, TX). Briefly, siRNA for Bcl-2, Bcl-xL, catalase and controls were incubated with Lipofectamine ${ }^{\mathrm{TM}}$ RNAiMAX in Opti-MEM I medium (Invitrogen) for $20 \mathrm{~min}$ at room temperature. They were then added to cell culture media without antibiotics. Media were replaced $24 \mathrm{~h}$ post-transfection. Cells were treated with or without $\mathrm{NiCl}_{2}$ for another $24 \mathrm{~h}$. Cell lysates or cells were collected either for western blot or apoptosis analysis as mentioned above.

Retrovirus infection. GFP labeled p-MIG, p-MIG-Bcl-2, pMIG-Bcl-xL retroviral vector (17) were kind gifts from Dr Stanley Korsmeyer, Dana-Farber Cancer Institute, USA
(Addgene, \#9044,\#3541, \#3544). The plasmids were transfected into 293-GPG cell using Lipofectamine 2000 reagent, viruses were produced in 293-GPG cells with subsequent centrifugation, filtration and stored at $-20^{\circ} \mathrm{C}$. BEAS-2B or T-BEAS-2B cells were then infected with control, $\mathrm{Bcl}-2, \mathrm{Bcl}-\mathrm{xL}$ retroviruses by adding virus solution into the cells with polybrene for $48 \mathrm{~h}$ before they were used for apoptosis and western blot analysis, virus infection in cells was monitored by checking GFP under fluorescence microscope.

Tumor xenograft model. Athymic nude (nu/nu) female mice, 5 weeks old and weighing about 18 to $20 \mathrm{~g}$ were purchased from Jackson Laboratory (Bar Harbor, MI). Mice were handled following the University of Kentucky guidelines for care and use of laboratory animals and approved by the ethical committee. BEAS-2B or transformed BEAS-2B cells $\left(2 \times 10^{6}\right)$ were mixed with Matrigel and injected in both side of flank region in $50 \mu \mathrm{l}$ volume. Five animals in each group gave 10 injection sites. Mice were fed normally, the body weight, and tumor growth was monitored twice weekly until the tumor size reached $1 \times 1 \times 1 \mathrm{~cm}^{3}$ in size or 8 weeks post inoculation.

Statistical analysis. All values are expressed as mean \pm standard error (SEM). Student's t-test was used to compare the difference between various controls and $\mathrm{NiCl}_{2}$-treated groups. P-value less than 0.05 was considered statistically significant.

\section{Results}

Transformed BEAS-2B cells have increased Bcl-2, Bcl-xL protein expression and are resistant to nickel-induced apoptosis. To evaluate $\mathrm{Bcl}-2, \mathrm{Bcl}-\mathrm{xL}$ protein expression and their role in nickel-induced apoptosis, BEAS-2B and transformed BEAS-2B (T-BEAS-2B) cells were first treated with or without $0.5,1$ and $1.5 \mathrm{mM}$ of $\mathrm{NiCl}_{2}$ for $24 \mathrm{~h}$ for apoptosis induction. At 0.5 , and $1 \mathrm{mM}$ doses, only BEAS-2B cells showed apoptosis induction in $24 \mathrm{~h}$, T-BEAS-2B cell showed little or no apoptosis (data not shown), therefore, $1.5 \mathrm{mM}$ of $\mathrm{NiCl}_{2}$ was selected for apoptosis induction in both types of cells.

BEAS-2B and T-BEAS-2B cells were treated with or without $1.5 \mathrm{mM}$ of $\mathrm{NiCl}_{2}$ for $24 \mathrm{~h}$ to analysis apoptosis. The results indicated that T-BEAS-2B cells had significantly lower level of apoptosis (Fig. 1A), but increased Bcl-2, and Bcl-xL protein expression (Fig. 1B and $\mathrm{C}$ ) when compared with control BEAS-2B cells. Following $\mathrm{NiCl}_{2}$ exposure, the Bcl-2, and $\mathrm{Bcl}-\mathrm{xL}$ protein expression declined in both type of cells, but control BEAS-2B cells had greater level of reduction than T-BEAS-2B cells (Fig. 1B and C). To understand if Bcl-2, and $\mathrm{Bcl}-\mathrm{xL}$ protein reduction might be due to $\mathrm{NiCl}_{2}$-induced transcriptional repression, quantitative RT-PCR assay was performed in both types of cells. Fig. 1D shows that Bcl-2 and Bcl-xL mRNA expression was repressed in BEAS-2B cells following $\mathrm{NiCl}_{2}$-treatment. Similar pattern of mRNA expression was also noted in T-BEAS-2B cells (data not shown). These results suggested a mechanism of $\mathrm{NiCl}_{2}$-induced gene transcription repression (Fig. 1D).

We tested if the levels of Bcl-2 and Bcl-xL protein expression in BEAS-2B and T-BEAS-2B cells might affect $\mathrm{NiCl}_{2}$-induced apoptosis. Forced overexpression of $\mathrm{Bcl}-2$, and $\mathrm{Bcl}-\mathrm{xL}$ protein with plasmids in BEAS-2B cells reduced $\mathrm{NiCl}_{2}$-induced cell 

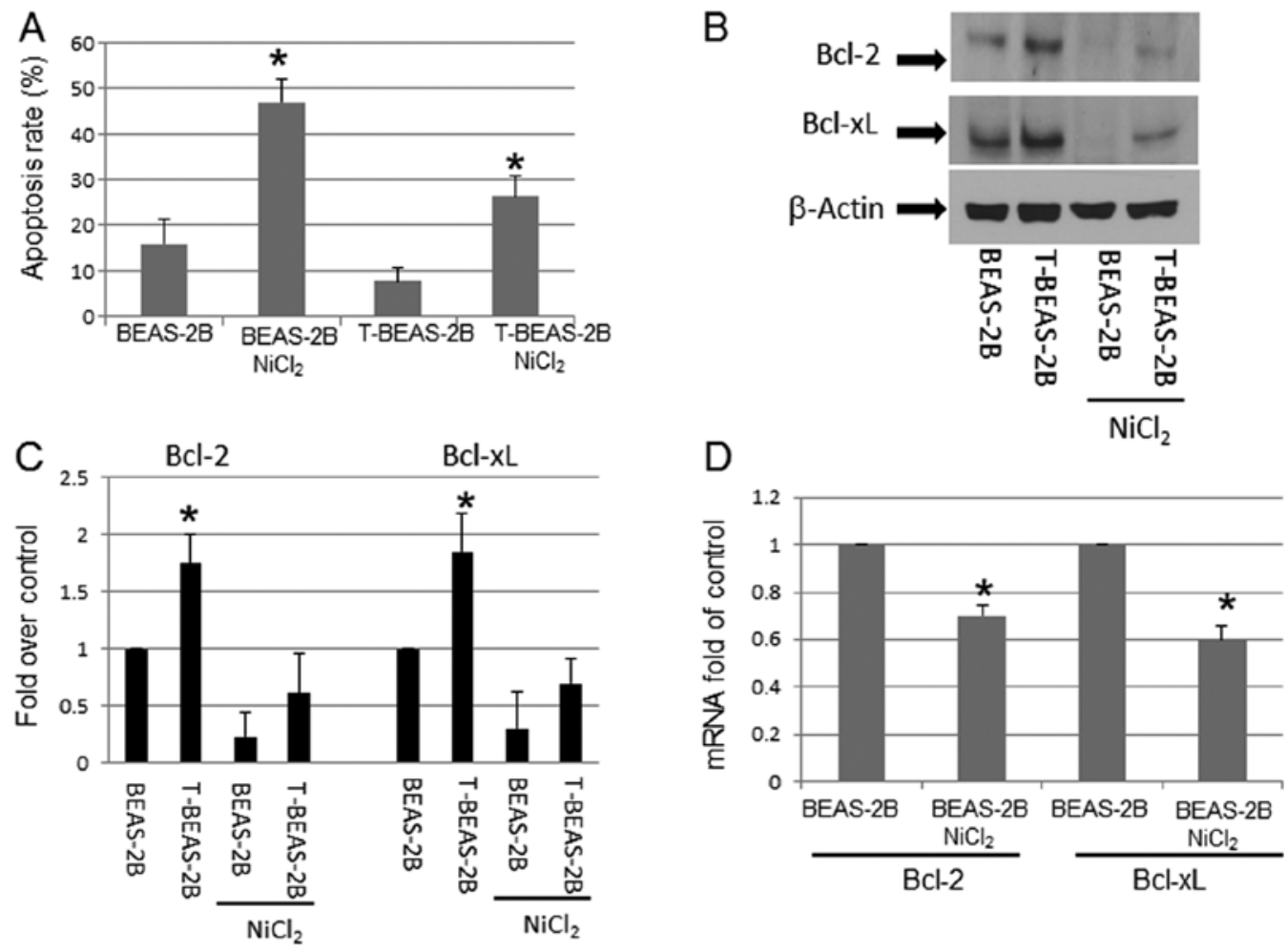

Figure 1. Transformed BEAS-2B cells are resistant to nickel-induced apoptosis. BEAS-2B or transformed BEAS-2B (T-BEAS-2B) cells $\left(1 \times 10^{6}\right)$ were treated with or without $1.5 \mathrm{mM}$ of $\mathrm{NiCl}_{2}$ for $24 \mathrm{~h}$. (A) Apoptosis was analyzed from the treated cells by Annexin V/PI staining followed by flow cytometry analysis. (B) Cell lysates were collected and resolved in 10\% SDS-PAGE to detect respective protein expression, arrows indicate the specific band. (C) Scanned densitometry data were expressed as arbitrary unit and adjusted as fold changes over the control. (D) Bcl-2 and Bcl-xL mRNA expression from the treated BEAS-2B cells were determined by real-time PCR as stated in Materials and methods. Data are mean \pm SEM from 3-4 separate experiments. "P $<0.05$ when compared with control cells.

A

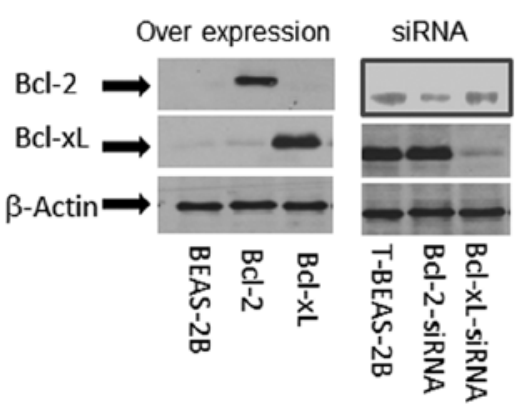

B

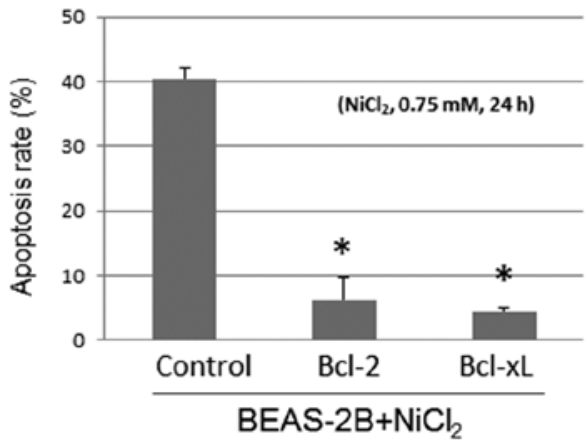

C
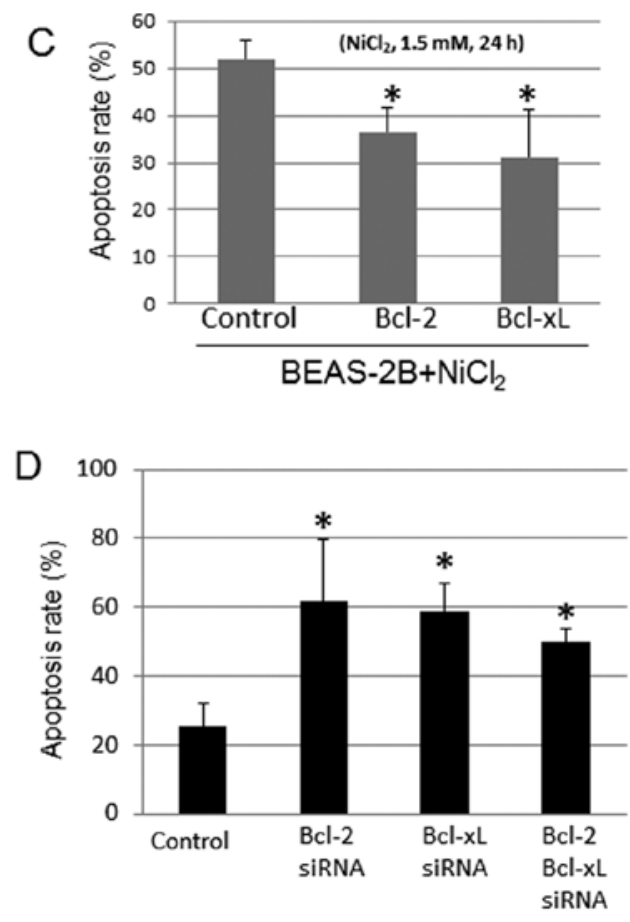

$\mathrm{T}-\mathrm{BEAS}-2 \mathrm{~B}+\mathrm{NiCl}_{2}$

Figure 2. Effects of $\mathrm{Bcl}-2$, and $\mathrm{Bcl}-\mathrm{xL}$ expression in $\mathrm{NiCl}_{2}$-induced apoptosis. BEAS-2B cells were infected with control empty vector, $\mathrm{Bcl}-2$, and $\mathrm{Bcl}-\mathrm{xL}$ retrovirus (control, Bcl-2, Bcl-xL), transformed BEAS-2B cells (T-BEAS-2B) were transfected with control, Bcl-2, and Bcl-xL siRNA (siRNA). Cells were treated with or without $\mathrm{NiCl}_{2}$ at 0.75 and $1.5 \mathrm{mM}$ for $24 \mathrm{~h}$. To determine Bcl-2, and Bcl-xL specific protein expression, cell lysates were collected from the retrovirus infected and siRNA transfected cells (A). Protein $(20 \mu \mathrm{g})$ was resolved in 10\% SDS-PAGE to detect the respective protein expression. Blots are representative of 2-3 separate experiments with similar results, arrows indicate the specific band. Apoptosis was assayed using either Annexin V/PI (B and C) or Hoechst 33342/PI staining (D) followed by flow cytometry analysis. Data are mean \pm SEM from three separate experiments, " $\mathrm{P}<0.05$ when compared with controls. 
A
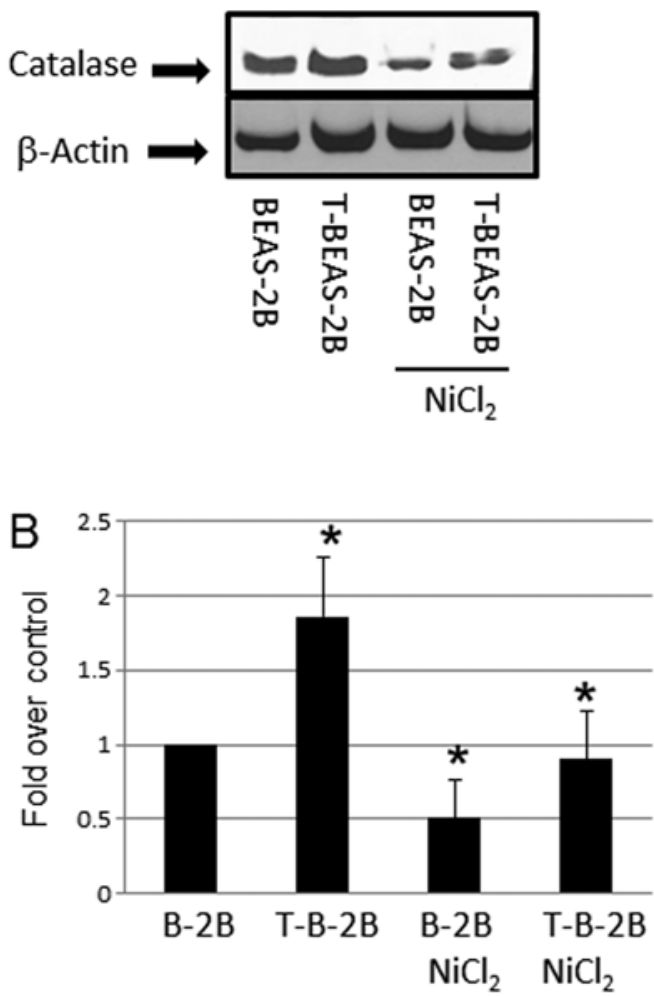

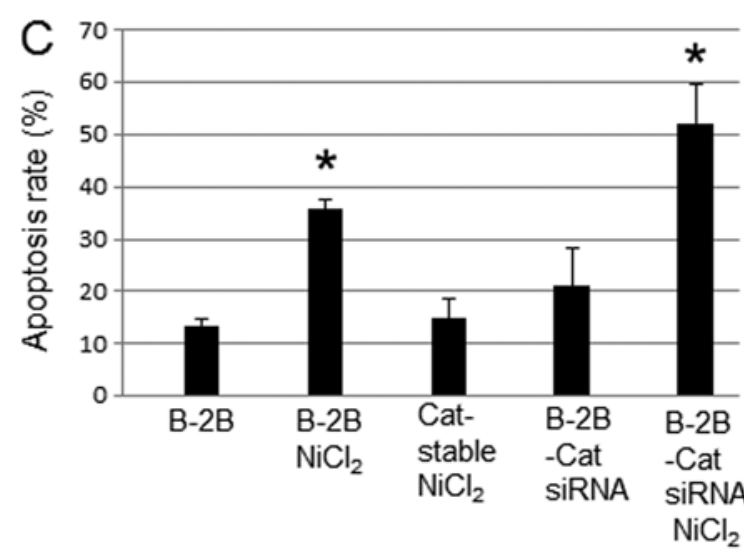

$\mathrm{D}$

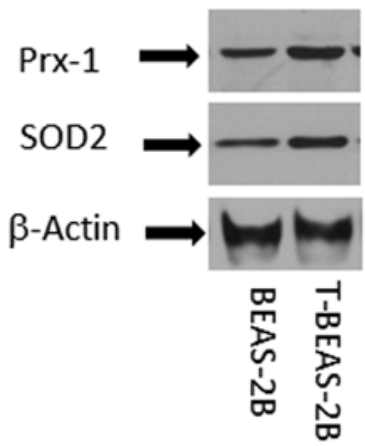

Figure 3. Effects of catalase in $\mathrm{NiCl}_{2}$-induced apoptosis. BEAS-2B (B-2B), transformed BEAS-2B (T-BEAS-2B, T-B-2B) $\left(1 \times 10^{6}\right)$ were treated with or without $\mathrm{NiCl}_{2}$ at $1.5 \mathrm{mM}$ for $24 \mathrm{~h}$. Cell lysates were collected and resolved in 10\% SDS-PAGE to detect catalase and other ROS scavenge proteins expression (A-C), blots are representative of 2-3 separate experiments with similar results. Arrows indicate the specific band. Densitometry data from catalase were scanned as arbitrary unit and adjusted as fold changes over the control (B). To determine the role of catalase in $\mathrm{NiCl}_{2}$-induced apoptosis (D), BEAS-2B (B-2B) cells were transfected with or without catalase siRNA (B-2B-Cat-siRNA) for $48 \mathrm{~h}$. Cells were treated with or without $\mathrm{NiCl}_{2}$ at $1.5 \mathrm{mM}$ for another $24 \mathrm{~h}$. BEAS-2B catalase-stable expressing cells (Cat-stable) also received the same treatment. Apoptosis was assayed by Annexin V/PI staining followed by flow cytometry analysis (D). Data are mean \pm SEM from three separate experiments, ${ }^{*} \mathrm{P}<0.05$ when compared with control cells.

apoptosis in a dose-dependent manner (Fig. 2A-C). In contrast, siRNA knockdown of Bcl-2, and Bcl-xL protein expression in T-BEAS-2B cells enhanced the apoptosis rate (Fig. 2A and D). These results suggested that the relative levels of Bcl-2, and $\mathrm{Bcl}-\mathrm{xL}$ protein are important for apoptosis induction/resistance in both types of cells.

Effects of catalase in $\mathrm{NiCl}_{2}$-induced apoptosis. After cell transformation, ROS generation is reduced in transformed cells, a mechanism that attributed to increased ROS scavenging enzyme expression (18). We examined if the apoptosis resistance in $\mathrm{NiCl}_{2}$-transformed cells are accompanied by higher ROS scavenging proteins expression. The results showed upregulation of catalase in nickel-transformed cells over the controls (Fig. 3A and B). Overexpression of catalase by using a stable cell line reduced $\mathrm{NiCl}_{2}$-induced apoptosis; in contrast, using catalase siRNA to reduce its expression (data not shown) enhanced apoptosis (Fig. 3C). These results suggested that catalase or generation of ROS is important mechanism in $\mathrm{NiCl}_{2}$-induced apoptosis. Western blot analysis also indicated that other ROS scavenging enzymes such as SOD2, and Prx-1 protein levels were increased in T-BEAS-2B cells when compared with control non-transformed BEAS-2B cells (Fig. 3D), while SOD1, and Phox47 protein expression showed no difference (data not shown). Thus, these results provide mechanistic explanation of reduced ROS level in T-BEAS-2B cells as reported previously (9), and these mechanisms may contribute to the apoptosis resistance in transformed cells.

Transformed cells are resistant to $\mathrm{NiCl}_{2}$-induced mitochondria damage. To investigate whether transformed cells are resistant to mitochondria damage. We evaluated $\mathrm{NiCl}_{2}$-induced mitochondria damage in both types of cells and the role of $\mathrm{Bcl}-2$ and $\mathrm{Bcl}-\mathrm{xL}$ in these processes. The results showed that T-BEAS-2B cells are more resistant to $\mathrm{NiCl}_{2}$-induced mitochondrial damage compared with non-transformed BEAS-2B cells (Fig. 4A and B). Forced overexpression of Bcl-2, Bcl-xL and catalase largely abolished $\mathrm{NiCl}_{2}$-induced mitochondria damage in BEAS-2B cells (Fig. 4C and D). Significant difference was noted when the quantitative data were compared with control cells $\left({ }^{*} \mathrm{P}<0.05\right)$. These results indicated that enhanced $\mathrm{Bcl}-2, \mathrm{Bcl}-\mathrm{xL}$ and catalase protein expression are important mechanisms for reduced mitochondria damage in transformed cells.

Caspase activation in nickel-transformed cells. The above results demonstrated that T-BEAS-2B cells differ from BEAS-2B cells in $\mathrm{NiCl}_{2}$-induced apoptosis resistance and mitochondria damage; thus we further studied the underlying molecular mechanisms. We compared caspase activation in both types of cells. The 
A

BEAS-2B

$+\mathrm{NICl}_{2}$

$+\mathrm{NiCl}_{2}$

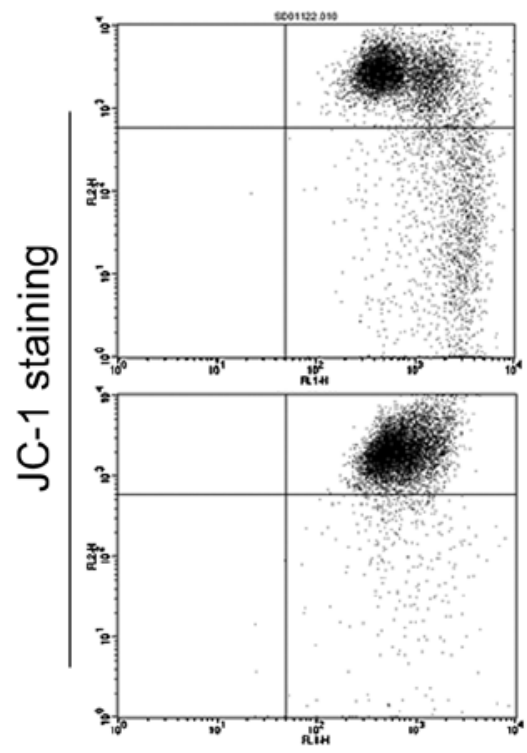

C

BEAS-2B Control

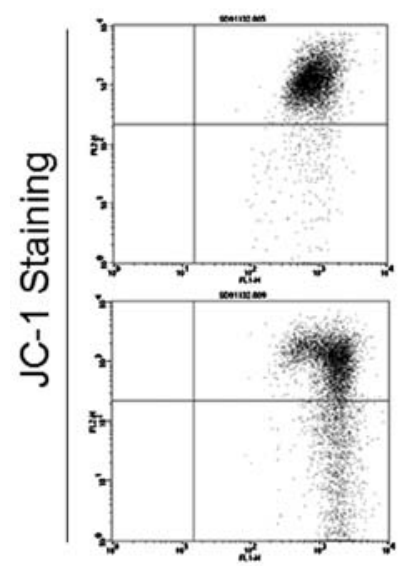

BEAS-2B

Control

$\mathrm{NiCl}_{2}$
BEAS-2B

$\mathrm{Bcl}-2$
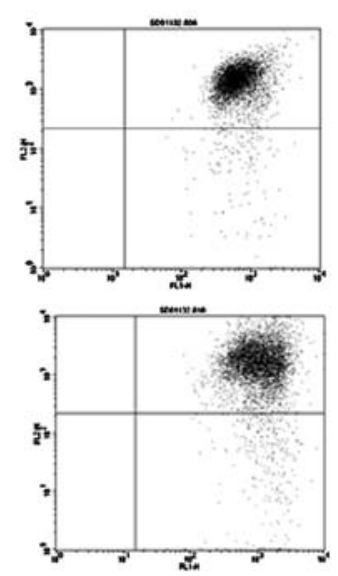

BEAS-2B

$\mathrm{Bcl}-2$

$\mathrm{NiCl}_{2}$
B

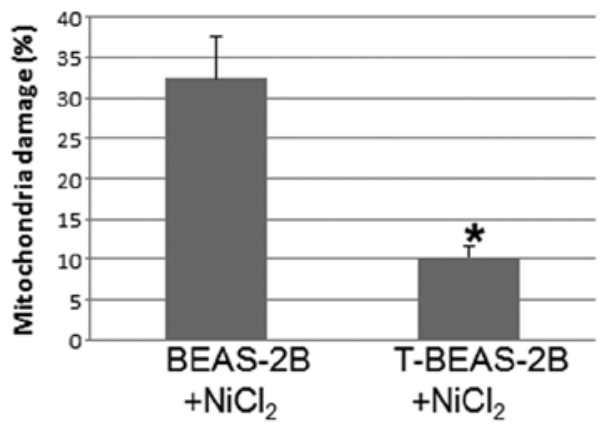

BEAS-2B

BEAS-2B

Cat-stable
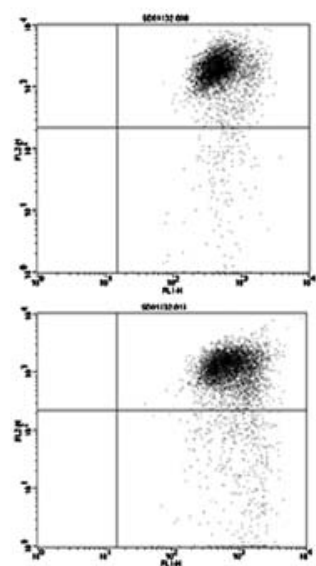

BEAS-2B

$\mathrm{Bcl}-\mathrm{XL}$

$\mathrm{NiCl}_{2}$
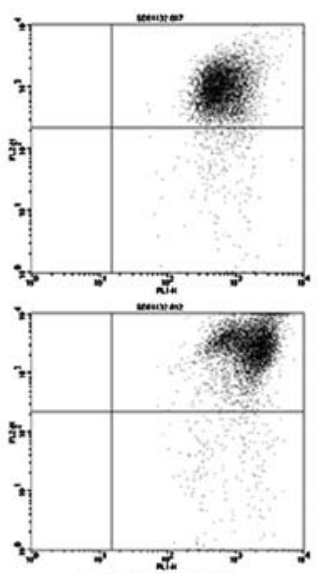

BEAS-2B

Cat-stable

$\mathrm{NiCl}_{2}$

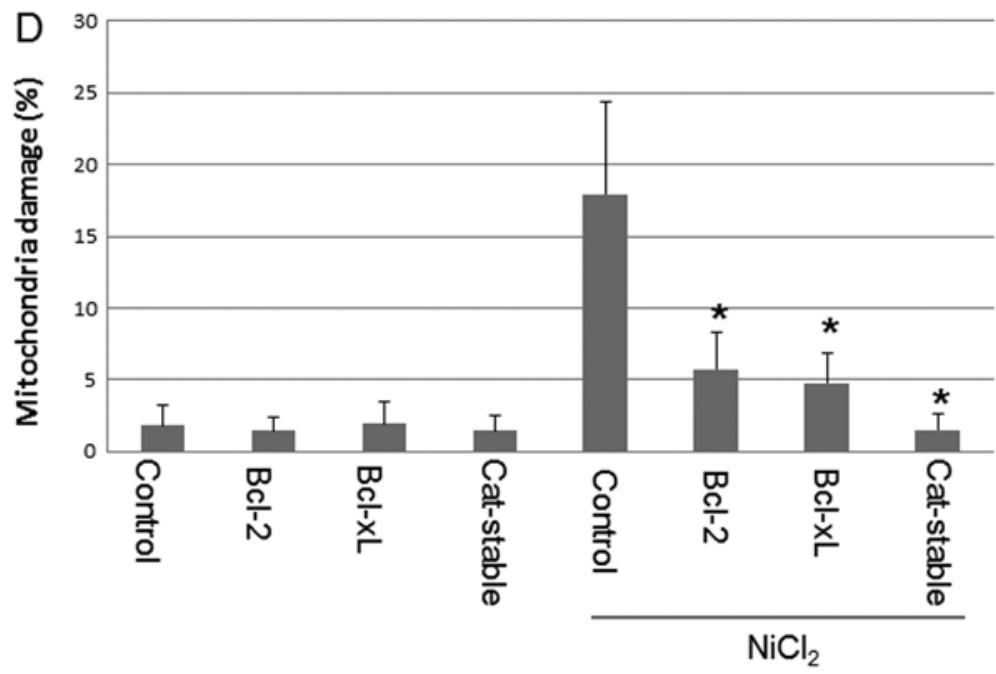

Figure 4. Transformed cells are resistant to $\mathrm{NiCl}_{2}$-induced mitochondria damage. To evaluate $\mathrm{NiCl}_{2}$-induced mitrochodria damage, $\mathrm{BEAS}-2 \mathrm{~B}$, transformed $\mathrm{BEAS}-2 \mathrm{~B}$ (T-BEAS-2B), control empty vector, Bcl-2, and Bcl-xL-retrovirus infected BEAS-2B (control, Bcl-2, Bcl-xL) and BEAS-2B catalase-stable expressing cells (Catstable) $\left(1 \times 10^{6}\right)$ were treated with or without $\mathrm{NiCl}_{2}$ at $1.5 \mathrm{mM}$ for $16 \mathrm{~h}$. Cells were stained with JC-1 dye followed by flow cytometry analysis. (A and C) Representative images are shown; (B and D) quantification of three separate experiments are expressed as mean \pm SEM. (B and D) * $\mathrm{P}<0.05$ when compared with controls. 


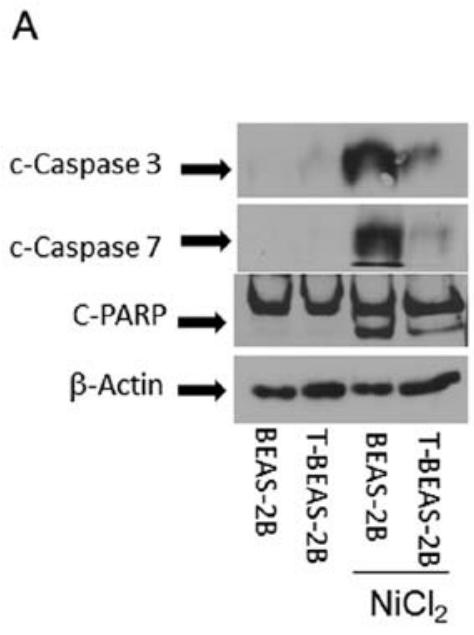

D

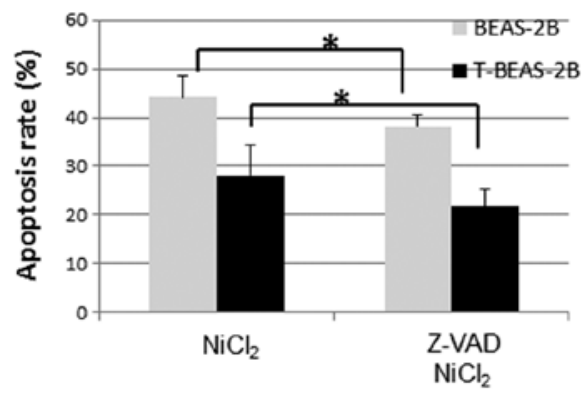

$\mathrm{F}$

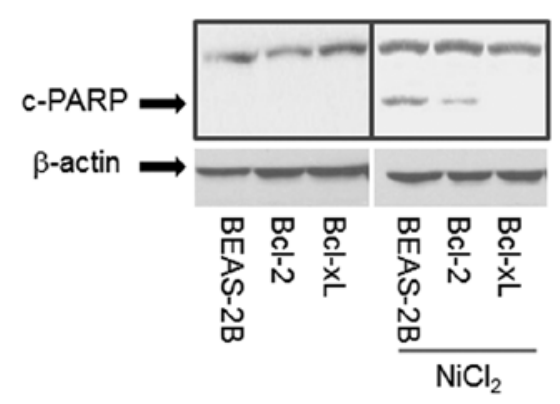

B

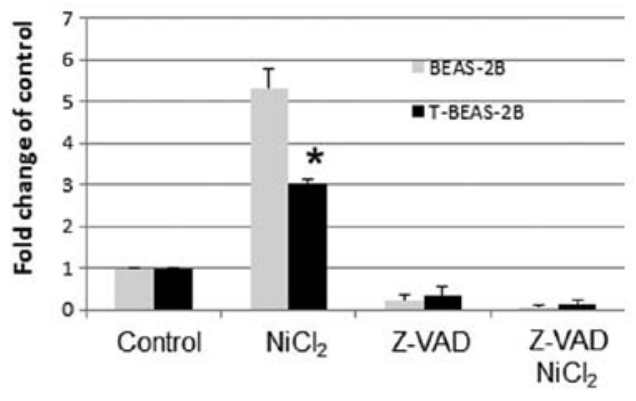

C

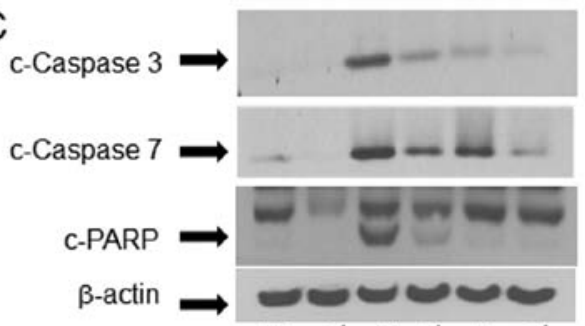

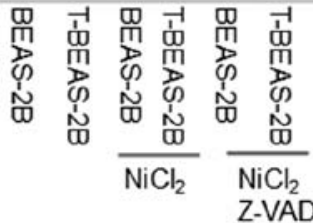

E

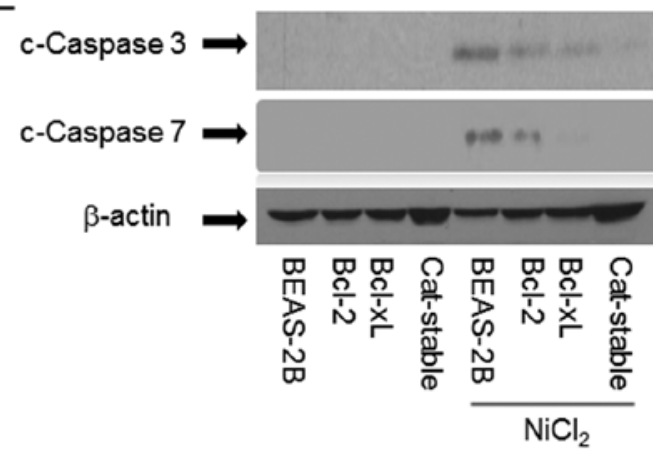

G

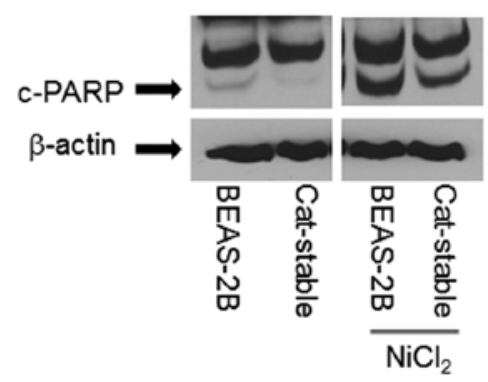

Figure 5. Caspase activation in nickel-transformed cells. BEAS-2B, transformed BEAS-2B (T-BEAS-2B), control empty vector, Bcl-2, and Bcl-xL-retrovirus infected BEAS-2B (Bcl-2, Bcl-xL) and BEAS-2B catalase-stable expressing cells (Cat-stable) $\left(1 \times 10^{6}\right)$ were treated with or without $\mathrm{NiCl}_{2}$ at $1.5 \mathrm{mM}$ for $24 \mathrm{~h}$. Cell lysate was collected and $20 \mu \mathrm{g}$ of protein resolved in 10\% SDS-PAGE to detect respective protein expression (A, C,E-G). Blots are representative from 3-4 separate experiments with similar results, arrows indicate the specific band. To determine caspase 3/7 enzymatic activity, BEAS-2B and T-BEAS-2B cells were treated with or without $\mathrm{NiCl}_{2}$ at $1.5 \mathrm{mM}$ for $16 \mathrm{~h}$ and enzymatic activity was assayed as described in Materials and methods (B). For apoptosis assay, BEAS-2B, transformed BEAS-2B (T-BEAS-2B) cells were treated with or without $\mathrm{NiCl}_{2}$ at $1.5 \mathrm{mM}$ and Z-VAD for $24 \mathrm{~h}$, apoptosis was assayed using the Annexin V/PI staining followed by flow cytometry (D). Quantitative data are expressed as mean \pm SEM from three separate experiments, ${ }^{*} \mathrm{P}<0.05$ when compared with respective controls.

result in Fig. 5 clearly indicates that upon $\mathrm{NiCl}_{2}$ stimulation, BEAS-2B cells had much stronger caspase activation, presented as increased c-caspase 3,7 and c-PARP protein expression when compared with T-BEAS-2B cells (Fig. 5A). This was accompa- nied by increased caspase 3/7 enzymatic activity, while Z-VAD, a pan-caspase inhibitor, blocked the caspase $3 / 7$ enzymatic activity (Fig. 5B), reduced c-caspase 3, 7 expression (Fig. 5C), and attenuated apoptosis (Fig. 5D). 
A

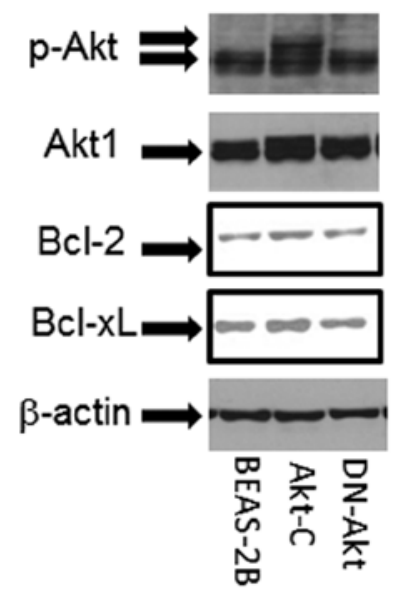

$\mathrm{B}$
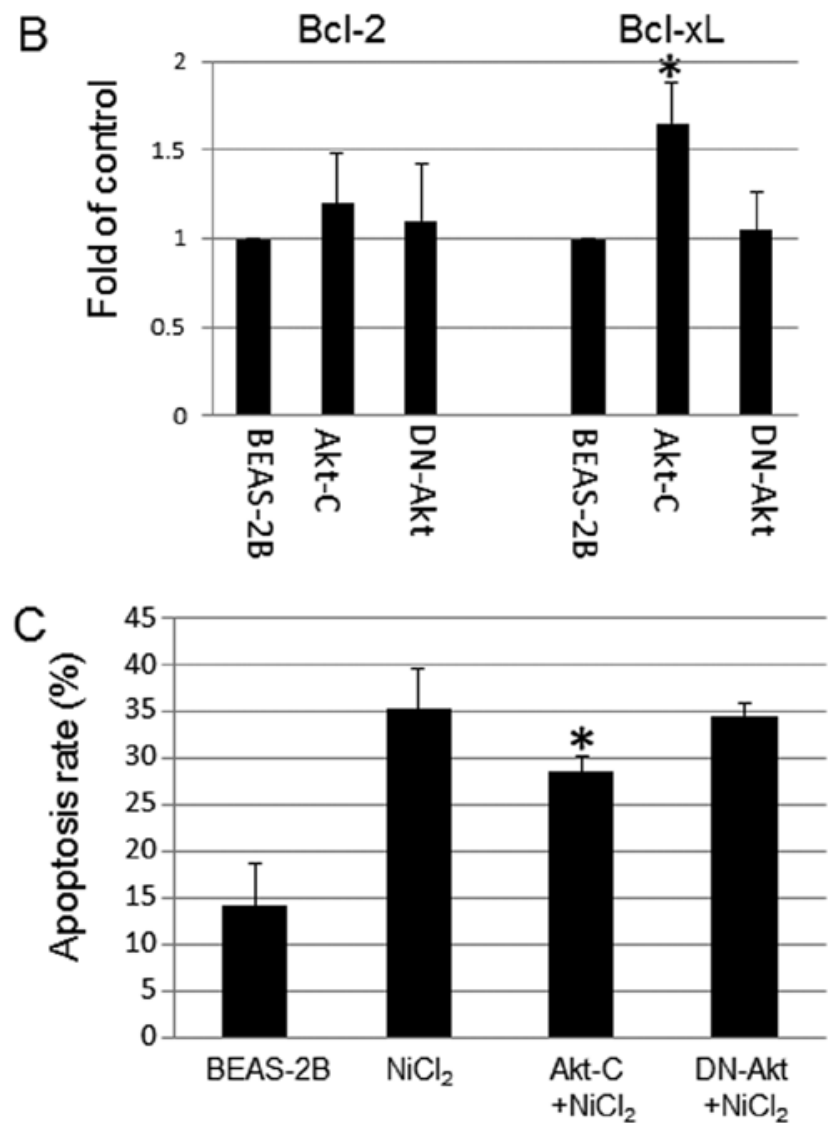

Figure 6. Effects of Akt expression in $\mathrm{NiCl}_{2}$-induced apoptosis. BEAS-2B and BEAS-2B stably expressing Akt (Akt-C), dominate negative-Akt (DN-Akt) cells were treated with or without $\mathrm{NiCl}_{2}$ at $1.5 \mathrm{mM}$ for $24 \mathrm{~h}$. Cell lysates were collected and $20 \mu \mathrm{g}$ of protein was resolved in $10 \%$ SDS-PAGE to detect protein expression. Blots are representative of three separate experiments with similar results. (A) Arrows indicate the specific band. (B) Scanned densitometry data are expressed as arbitrary units and adjusted as fold changes over the control. (C) Apoptosis was determined by Annexin V/PI staining followed by flow cytometry analysis. Data are mean \pm SEM from three separate experiments, ${ }^{*} \mathrm{P}<0.05$ when compared with control cells.

In addition, we evaluated if $\mathrm{Bcl}-2, \mathrm{Bcl}-\mathrm{xL}$ and catalase proteins that are overexpressed in T-BEAS-2B cell may antagonize the $\mathrm{NiCl}_{2}$-induced caspase activation. The results indicated that overexpression of $\mathrm{Bcl}-2, \mathrm{Bcl}-\mathrm{xL}$ and catalase protein effectively reduced the c-caspase 3,7 and c-PARP protein expression (Fig. 5E-G), respectively, correlating with reduced mitochondria damage and apoptosis. Therefore, these results demonstrated that upregulation of Bcl-2, Bcl-xL and catalase in T-BEAS-2B suppresses caspase activation, which are essential mechanisms underlying the adapted apoptosis resistance in these cells.

Role of p-Akt in $\mathrm{NiCl}_{2}$ induced-apoptosis. p-Akt expression was upregulated in T-BEAS-2B cells in a previous study (9). To understand its role in $\mathrm{NiCl}_{2}$-induced apoptosis, we used Akt overexpression (Akt-C) and dominant negative Akt (DN-Akt) stable cell lines to determine the effects of Akt on $\mathrm{NiCl}_{2}$-induced apoptosis. The results indicated that Akt stable cells had persistently enhanced p-Akt level (Fig. 6A), and increased $\mathrm{Bcl}-\mathrm{xL}$ protein expression, but not $\mathrm{Bcl}-2$ expression; while in DN-Akt cells, Bcl-2, and Bcl-xL protein expression remain at the basal control level (Fig. 6A and $\mathrm{B}$ ). In addition, $\mathrm{NiCl}_{2}$ challenge induced marginally higher levels of apoptosis in control and DN-Akt cells over the Akt stable cells (Fig. 6C), pointing out the protective roles of $\mathrm{Akt}$ in $\mathrm{NiCl}_{2}$-induce BEAS-2B cell apopotsis.

Tumorigenic properties of $\mathrm{NiCl}_{2}$ transformed cells. To evaluate if the transformed cells are tumorigenic, we injected both control BEAS-2B and T-BEAS-2B cells into nude mice and observed the tumor growth. The results indicated that among five injected mice in each group, only T-BEAS-2B cells induced tumor growth, and tumors occurred at multiple injection sites, grew into various sizes within 8 weeks (Fig. 7A and B). Furthermore, western blot analysis revealed increased $\mathrm{HIF}-1 \alpha \mathrm{NF}-\kappa \mathrm{B}-\mathrm{p} 50$ subunit and p-Stat 3 protein expression in T-BEAS-2B cells when compared with non-transformed cells, underlying the oncogenic features of the $\mathrm{NiCl}_{2}$-transformed cells (Fig. 7C).

\section{Discussion}

Nickel is a known human carcinogen and induces genotoxic stress. A number of mechanisms have been proposed for its carcinogenic effects; such as generation of ROS, induction of DNA damage, and activation of oncogenic pathways (3). However, little information is available with regard to the mechanisms of apoptosis resistance in nickel-transformed 

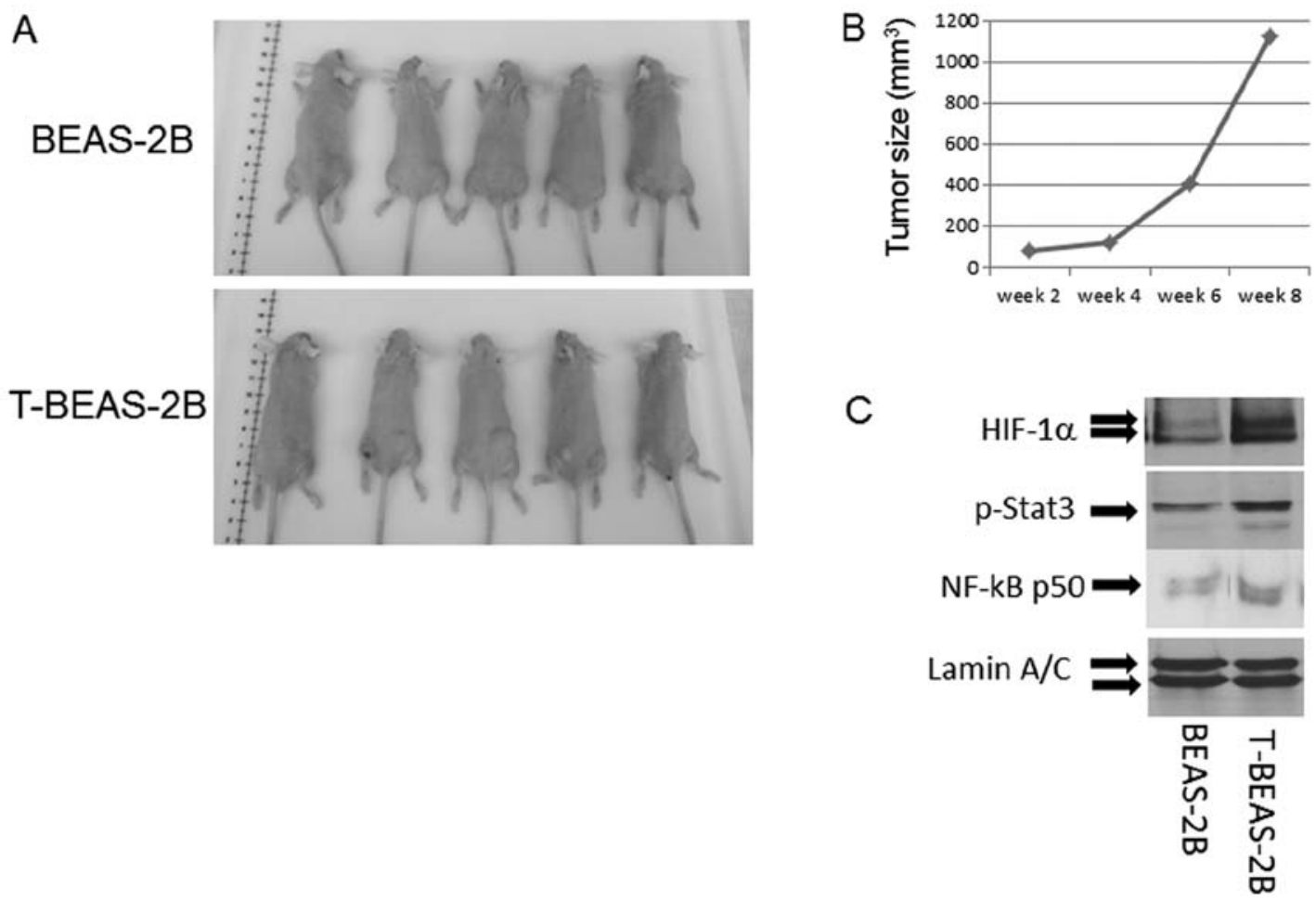

Figure 7. Tumorigenic properties of $\mathrm{NiCl}_{2}$-transformed cells. BEAS-2B or transformed BEAS-2B (T-BEAS-2B) cells $\left(2 \times 10^{6}\right)$ were mixed with matrigel and injected subcutaneously into athymic nude mice on both sides of flank region. (A and B) Five animals were injected in each group, tumor growth were monitored twice weekly until the tumor size reach $1 \times 1 \times 1 \mathrm{~cm}^{3}$ in size or by 8 weeks post inoculation. (C) To monitor the oncogenic protein expression in transformed BEAS-2B cells, cell lysates from each type of cell were collected and resolved in 10\% SDS-PAGE to detect p-Stat3, NF- $\mathrm{B}$-p50 subunit and HIF-1 $\alpha$ protein expression. Blots are representative of 3-4 separate experiments with similar results. Arrows indicate the specific band.

cells. In this study, we focused on apoptosis resistant and tumorigenic property of $\mathrm{NiCl}_{2}$-transformed human lung epithelial cells, and explored the potential molecular mechanisms. The results demonstrate that $\mathrm{NiCl}_{2}$ transformed BEAS-2B cells are resistant to apoptosis and tumorigenic. Higher levels of Bcl-2, Bcl-xL and catalase protein expression are important mechanisms contributing to the transformed cell oncogenic properties.

Previously in vitro studies have shown that waterinsoluble nickel compounds such as nickel oxide, nickel subsulfide are more readily phagocytized than the watersoluble nickel compounds such as nickel chloride. They can reach the nucleus of the cell in greater amounts than that of water-soluble nickel compounds and induce more cell damage $(19,20)$. In the current study, $\mathrm{NiCl}_{2}$ was selected due to the BEAS-2B cells being transformed by $\mathrm{NiCl}_{2}$ exposure (9). One important characteristic of nickel compounds is the generation of ROS in host cells, and ROS appear critical in nickel-induced cell damage, such as apoptosis and oncogenic transformation $(1,4)$. Increasing evidence has indicated that ROS plays an important role in inducing apoptosis and carcinogenesis following diverse exposure to environmental stimuli (21). However, ROS generation in transformed cells is reduced $(9,18)$, the mechanism is not clear. In the current study, we confirm that antioxidant enzymes are increased in transformed cells including catalase, SOD2 and Prx-1 (22), suggesting that they are responsible for the reduced ROS generation in transformed cells $(9,18)$. Higher
ROS scavenging enzyme expression may also contribute to $\mathrm{NiCl}_{2}$-induced apoptosis resistance in transformed cells by attenuating the detrimental effects from ROS generated by $\mathrm{NiCl}_{2}$ exposure. However, the biological implications of these changes during transformation have yet to be explored, as well as the molecular mechanisms that result in their increased expression in transformed cells. The data provide evidence that transformation involves multiple cellular signal alternations, which deserve further investigation.

$\mathrm{Bcl}-2$ and $\mathrm{Bcl}-\mathrm{xL}$ proteins are overexpressed in a variety of human cancers (23), and are important members of antiapoptotic proteins family. The mechanisms of Bcl-2 and Bcl-xL protect cells from apoptosis through either heterodimerization with pro-apoptotic proteins, or their direct pore-blocking effects on the outer membrane of mitochondria $(11,23)$. Mitochondria play a critical role in apoptosis induction, which involves both caspase-dependent and -independent pathways. We noted that $\mathrm{NiCl}_{2}$-induced apoptosis can be affected by both Bcl-2 and Bcl-xL expressing vector and siRNA transfection, indicating that their relative levels regulate cell apoptosis resistance in T-BEAS-2B cells. The question of how transformed cell evolve into higher level of $\mathrm{Bcl}-2$, and $\mathrm{Bcl}-\mathrm{xL}$ protein expression remain to be investigated, we hypothesis that either genetic or epigenetic modifications may be responsible during the transformation and selection processes.

In our study, $\mathrm{NiCl}_{2}$ treatment reduced the cellular level of $\mathrm{Bcl}-2$ and Bcl-xL proteins in both transformed and non-trans- 
formed cells (Fig. 1A and B), but the level of reduction in transformed cells is less dramatic, which is associated with low apoptotic rate. This effect also correlates with reduced mitochondrial stress, c-caspase 3,7 protein level, caspase enzymatic activity and PARP cleavage. Together, they suggest that transformed cells evolve a mechanism of increased Bcl-2/Bcl-xL protein expression, reduced mitochondrial stress and alleviated caspase activation upon $\mathrm{NiCl}_{2}$ exposure, therefore, confer these cells the apoptosis resistant property.

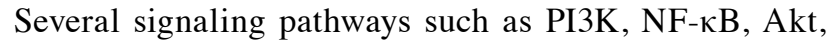
and Sonic hedgehog have been shown to regulate Bcl-2 and Bcl-xL protein expression and apoptosis in different cell types $(12,24,25)$. Induction of cyclooxygenesis 2 is also important in nickel induced apoptosis (26). In the current study, we focus on the effects of Bcl-2, Bcl-xL, and catalase by examining their roles in apoptosis resistance in transformed cells, as they are either the effector proteins downstream of the above mentioned signal pathways or involved in ROS generation. Akt is a serine/threonine kinase, also known as protein kinase $\mathrm{B}$ (PKB). It is involved in regulating multiple cellular functions, including cell growth, proliferation, survival, glucose metabolism and genome stability $(27,28)$. Aberrant Akt activation has been noted in breast, prostate, lung, pancreatic, liver, ovarian and colorectal cancers, and in malignant transformation (27-30). Akt overexpression enhances Bcl-xL expression, which is correlated with the fact that Akt-stable expressing cells are more resistant to $\mathrm{NiCl}_{2}$-induced apoptosis. The results uncovered anti-apoptotic protein-dependent mechanism in nickel-induced apoptosis resistance in transformed cells.

It is worth noting that overexpression of Akt could not completely block the nickel-induced apoptosis (Fig. 6), and even this effect was marginal. Since there are two major apoptotic pathways, the death-receptor pathway and the mitochondrial pathway, we consider other signal pathways might also contribute to the nickel-induced apoptosis. It has been reported that increased FasL expression, cell cycle alteration, activation of c-Myc through ERK pathway, caspase-8/AIF-mediated pathways, and activation of NF- $\mathrm{NB} / \mathrm{Cox} 2$ pathway all participate in nickel-induced apoptosis (26,31-34). Therefore, each may initiate and contribute to the pathway or cell type-specific apoptosis processes in additional to the mechanisms discussed in the present study. However, increased Bcl-2, Bcl-xL and catalase protein expression, reduced mitochondria damage and caspase activation described here appear to be the essential mechanisms involved in $\mathrm{NiCl}_{2}$-mediated cell death resistance program in transformed BEAS-2B cells. Future investigations will be required to clarify if other mechanisms might also be involved in transformed cell resistance to apoptosis.

One important feature of transformed cells is their tumorigenic property. These cells also have enhanced p-Stat $3, \mathrm{NF}-\kappa \mathrm{B}-\mathrm{p} 50$ subunit, and HIF-1 $\alpha$ protein expression. The altered oncogene expression probably reflects extensive genetic or epigenetic rearrangements during the transformation processes which allow transformed cells to adopt and grow in a new environment. It is also possible that they acquire cancer stem cell trait to allow cell resistant apoptosis. Future studies focusing on nickel-induced apoptosis resistance and cell transformation are of great interest to understand nickelinduced carcinogenic mechanisms and to provide options for prevention.

\section{Acknowledgements}

This research was supported in part by NIH grants (1R01CA119028) and a Henan provincial government biomedical key research grant (132102310444).

\section{References}

1. Costa M: Molecular mechanisms of nickel carcinogenesis. Annu Rev Pharmacol Toxicol 31: 321-337, 1991.

2. Doll R, Morgan LG and Speizer FE: Cancers of the lung and nasal sinuses in nickel workers. Br J Cancer 24: 623-632, 1970.

3. Costa M, Davidson TL, Chen H, et al: Nickel carcinogenesis: epigenetics and hypoxia signaling. Mutat Res 592: 79-88, 2005.

4. Lu H, Shi X, Costa M and Huang C: Carcinogenic effect of nickel compounds. Mol Cell Biochem 279: 45-67, 2005.

5. Salnikow K and Zhitkovich A: Genetic and epigenetic mechanisms in metal carcinogenesis and cocarcinogenesis: nickel, arsenic, and chromium. Chem Res Toxicol 21: 28-44, 2008.

6. Salnikow K and Costa M: Epigenetic mechanisms of nickel carcinogenesis. J Environ Pathol Toxicol Oncol 19: 307-318, 2000.

7. Davidson T, Chen H, Garrick MD, D'Angelo G and Costa M: Soluble nickel interferes with cellular iron homeostasis. Mol Cell Biochem 279: 157-162, 2005.

8. Pan J, Chang Q, Wang X, et al: Reactive oxygen species-activated Akt/ASK1/p38 signaling pathway in nickel compound-induced apoptosis in BEAS 2B cells. Chem Res Toxicol 23: 568-577, 2010.

9. Pan JJ, Chang QS, Wang X, et al: Activation of Akt/GSK3 $\beta$ and $\mathrm{Akt} / \mathrm{Bcl}-2$ signaling pathways in nickel-transformed BEAS-2B cells. Int J Oncol 39: 1285-1294, 2011.

10. Cory S and Adams JM: The Bcl2 family: regulators of the cellular life-or-death switch. Nat Rev Cancer 2: 647-656, 2002.

11. Gross A, McDonnell JM and Korsmeyer SJ: BCL-2 family members and the mitochondria in apoptosis. Genes Dev 13: 1899-1911, 1999.

12. Pugazhenthi S, Nesterova A, Sable C, et al: Akt/protein kinase $\mathrm{B}$ up-regulates $\mathrm{Bcl}-2$ expression through cAMP-response element-binding protein. J Biol Chem 275: 10761-10766, 2000.

13. Ding SZ, Yang YX, Li XL, et al: Epithelial-mesenchymal transition during oncogenic transformation induced by hexavalent chromium involves reactive oxygen species-dependent mechanism in lung epithelial cells. Toxicol Appl Pharmacol 269: 61-71, 2013

14. Zhou BP, Hu MC, Miller SA, et al: HER-2/neu blocks tumor necrosis factor-induced apoptosis via the Akt/NF-kappaB pathway. J Biol Chem 275: 8027-8031, 2000.

15. Ding SZ, Fischer W, Kaparakis-Liaskos M, et al: Helicobacter pylori-induced histone modification, associated gene expression in gastric epithelial cells, and its implication in pathogenesis. PLoS One 5: e9875, 2010.

16. Cossarizza A, Baccarani-Contri M, Kalashnikova G and Franceschi C: A new method for the cytofluorimetric analysis of mitochondrial membrane potential using the J-aggregate forming lipophilic cation 5,5',6,6'-tetrachloro-1,1',3,3'-tetraethylbenzimidazolcarbocyanine iodide (JC-1). Biochem Biophys Res Commun 197: 40-45, 1993.

17. Cheng EH, Wei MC, Weiler S, et al: BCL-2, BCL-X(L) sequester $\mathrm{BH} 3$ domain-only molecules preventing $\mathrm{BAX}$ - and BAK-mediated mitochondrial apoptosis. Mol Cell 8: 705-711, 2001.

18. Chang Q, Pan J, Wang X, Zhang Z, Chen F and Shi X: Reduced reactive oxygen species-generating capacity contributes to the enhanced cell growth of arsenic-transformed epithelial cells. Cancer Res 70: 5127-5135, 2010.

19. Dunnick JK, Elwell MR, Radovsky AE, et al: Comparative carcinogenic effects of nickel subsulfide, nickel oxide, or nickel sulfate hexahydrate chronic exposures in the lung. Cancer Res 55: 5251-5256, 1995.

20. Oller AR, Costa M and Oberdorster G: Carcinogenicity assessment of selected nickel compounds. Toxicol Appl Pharmacol 143: 152-166, 1997.

21. Zhao J, Shi X, Castranova V and Ding M: Occupational toxicology of nickel and nickel compounds. J Environ Pathol Toxicol Oncol 28: 177-208, 2009.

22. Kim YJ, Ahn JY, Liang P, Ip C, Zhang Y and Park YM: Human prx1 gene is a target of Nrf2 and is up-regulated by hypoxia/reoxygenation: implication to tumor biology. Cancer Res 67: 546-554, 2007. 
23. Yip KW and Reed JC: Bcl-2 family proteins and cancer. Oncogene 27: 6398-6406, 2008.

24. Catz SD and Johnson JL: Transcriptional regulation of bcl-2 by nuclear factor kappa B and its significance in prostate cancer. Oncogene 20: 7342-7351, 2001.

25. Bigelow RL, Chari NS, Unden AB, et al: Transcriptional regulation of bcl-2 mediated by the sonic hedgehog signaling pathway through gli-1. J Biol Chem 279: 1197-1205, 2004.

26. Ding J, Zhang X, Li J, et al: Nickel compounds render anti-apoptotic effect to human bronchial epithelial BEAS-2B cells by induction of cyclooxygenase-2 through an IKKbeta/p65-dependent and IKKalpha- and p50-independent pathway. J Biol Chem 281: 39022-39032, 2006.

27. Lawlor MA and Alessi DR: PKB/Akt: a key mediator of cell proliferation, survival and insulin responses? J Cell Sci 114 2903-2910, 2001

28. Morley S, Wagner J, Kauppinen K, Sherman M and Manor D: Requirement for Akt-mediated survival in cell transformation by the dbl oncogene. Cell Signal 19: 211-218, 2007.

29. Bellacosa A, Kumar CC, Di Cristofano A and Testa JR: Activation of AKT kinases in cancer: implications for therapeutic targeting. Adv Cancer Res 94: 29-86, 2005.
30. Manning BD and Cantley LC: AKT/PKB signaling: navigating downstream. Cell 129: 1261-1274, 2007.

31. Li Q, Suen TC, Sun H, Arita A and Costa M: Nickel compounds induce apoptosis in human bronchial epithelial Beas-2B cells by activation of c-Myc through ERK pathway. Toxicol Appl Pharmacol 235: 191-198, 2009.

32. Ding J, He G, Gong W, et al: Effects of nickel on cyclin expression, cell cycle progression and cell proliferation in human pulmonary cells. Cancer Epidemiol Biomarkers Prev 18: 1720-1729, 2009.

33. Kim K, Lee SH, Seo YR, Perkins SN and Kasprzak KS: Nickel(II)-induced apoptosis in murine T cell hybridoma cells is associated with increased fas ligand expression. Toxicol Appl Pharmacol 185: 41-47, 2002.

34. Zhao J, Bowman L, Zhang X, et al: Metallic nickel nano- and fine particles induce JB6 cell apoptosis through a caspase-8/AIF mediated cytochrome c-independent pathway. J Nanobiotechnol 7: 2, 2009. 